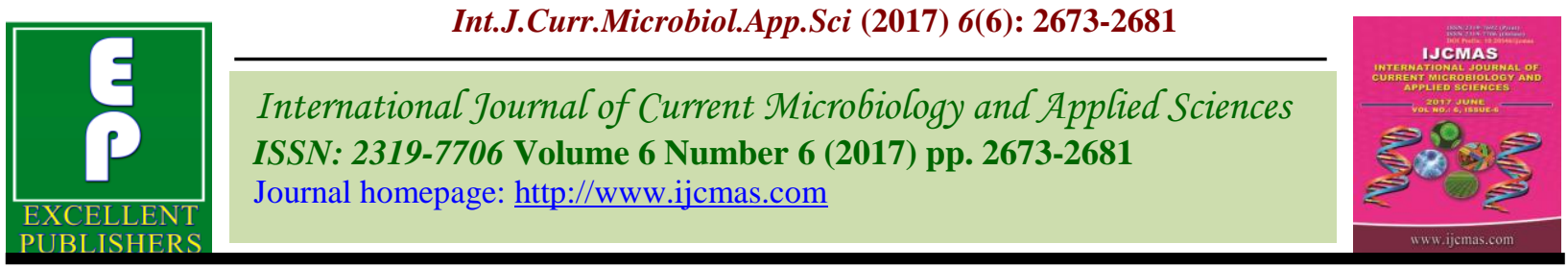

Original Research Article

https://doi.org/10.20546/ijcmas.2017.606.318

\title{
Agribusiness Opportunity for Pulse Growing Farmers in Bihar: A Situation Analysis
}

\author{
Meera Kumari $^{1 *}$, S.L. Bairwa ${ }^{2}$, L.K. Meena ${ }^{1}$ and Sk.M. Rahaman ${ }^{1}$ \\ ${ }^{1}$ Department of Agricultural Economics, Bihar Agricultural University, Sabour, \\ Bhagalpur-813210, India \\ ${ }^{2}$ Department of Agricultural Economics, Dr. Kalam Agricultural College, \\ Kisanganj, Bihar, India \\ *Corresponding author
}

\section{Keywords \\ Agribusiness, Growth trend, Consumption, Preferred traits, Chickpea, Dal Mill. \\ Article Info \\ Accepted: \\ 26 May 2017 \\ Available Online: \\ 10 June 2017}

\section{A B S T R A C T}

Pulses occupy a unique position in Indian agriculture. It plays a vital role in fixing atmospheric nitrogen in to Nitrate and make the soil fertile. Banka district is one of the important pulse trading centers in Bihar. Agro climatic condition of Banka as well as Bhagalpur district of Bihar is suitable for main pulses like chickpea and pigeon pea cultivation. An effort has been made to prove the leverage of suitable agro- climatic condition for the pulse crops and agribusiness opportunity available in that area. Growth and instability of major pulses shown significant but negative growth in area and production however productivity of chickpea shown positive growth rate over the period of time. As chickpea is cheapest source of protein and has multipurpose use, especially in Bhagalpur district people used it as Bessoon, Sattu and whole chana dall and also as substitute of vegetable during the off season when the price of vegetable in market is very high, people could not afford to buy it. Crop utilization of main product and by products of traditionally grown variety hardly sold in market by the farmers, better taste having high demand in the market is the most preferred traits for consumption and marketing of the produce of chickpea in Bihar. It was mainly used for consumption purpose in both of district. Despite of these fact available dall Mills in the region was very few in numbers. Instead of depending upon only farming; farmers can go for subsidiary agribusiness. "Mini dall mill" and processing of sattu can be a good agribusiness in that area. As it required less investment and can gets good return. Government subsidy is also available for the same. Farmers, self-help group (SHG), small entrepreneur, unemployed youth can leverage this opportunity and can start their own agribusiness.

\section{Introduction}

Pulses occupy a unique position in Indian agriculture. It is most suitable crop for dry land farming. It is a protein rich staple food and consumed in the form of split pulse as Dal. It contains about 22 percent protein, which is almost three times that of cereals. Pulses in India have long been considered as the poor man's only source of protein. Pulses are grown on 23 million hectares of area with an annual production of 15 million tons in 2003-04; it has been increased to 25 million hectares in the year 2013-14 and production during the same has been increased from 15 to19.7 million tones. However productivity 
has been increased from $635 \mathrm{Kg} / \mathrm{ha}$ to $785 \mathrm{Kg} / \mathrm{ha}$ during the same period respectively (Suhasini et al., 2013). Due to stagnant production, the net availability of pulses has come down from $60 \mathrm{gm} /$ day/person in 1951 to $31 \mathrm{gm} /$ day/person (Indian Council of Medical Research recommends $65 \mathrm{gm} /$ day/capita) in 2008. The requirement of pulses will continue to increase in future mainly due to ever increasing population and preference for pulses as the cheapest source of dietary protein. Our prime Minister call for second green revolution of the country with emphasis on enhancement of pulse production to ensure food and nutritional security of people also finds the Bihar is most suitable for it.

In the process of technological development in Bihar, pulse crops got major setback and its area declined from 6913 thousand hectares in 2003-04 to 500thousand hectare in the year 2013-14. It produces 562.6 thousand tones of pulses in 2003-04, which has been declined to522 thousand tones during2013-14 (Govt. of Bihar 2014). This is only $4 \%$ of pulse production of the country. However productivity of pulses has been increased from $814 \mathrm{Kg} / \mathrm{ha}$ to $1044 \mathrm{Kg} / \mathrm{ha}$ during the same period, which is higher than the national average. Definitely the Agricultural progress witnessed in our state in the last decade, there is ample scope for the state in enhancing the productivity of the individual pulses.

But emphasis will must be given on an increase in area of pulses bedside adoption of improved production and protection practices (Kumari et al., 2016). Among pulse crop grown in Bihar Lentil is the only pulse crop whose cropped area increased by 20,000 hectares. Its production is still greater to all India average $(991 \mathrm{~kg} / \mathrm{ha})$. Particular reference to major pulses like chickpea and pigeon pea in Bihar, the area and production of both the pulses has been declined, due to growing popularity and public policy emphasis on Rice-Wheat system (Anonymous, 2012). It has been noted that the area under pigeon pea declined over the year by 35 percent and that of chickpea and Lathyrus each by about 60 percent (compiled from data, Salam et al., 2013). It was estimated about 22 thousand hectare area of pigeon pea and 42 thousand metric tons production in 20012-13 and its productivity was about $1901 \mathrm{Kg} / \mathrm{ha}$ (DES, 2015).

It has been noticed that as irrigation facilities developed, chickpea gradually gets marginalized in Bihar and other parts of IndoGenetic Plains (Ranjan et al., 1996, 1998). In addition to this, there is a huge variability in area and production of major pulses during 2000-2009, however the productivity during the same period is more stable which indicates that there is a scope to increase production potential of major pulses in the state if adequate policy measures are taken (Kumari et al., 2015). In this regard it is pertinent to take into account the one million ha of rice fallow land in the state to which the chickpea and other pulses cultivation could be potentially expanded (F.A.O., 2009). It indicates state has huge potential in chick pea production. But as for marketing is concerned there is lack of established dal mils in the area at large scale so far have been observed (Kumari et al., 2016). Out of the marketed surplus, 80- 85 per cent produce traded outside the state mainly to Siliguri and Kolkata for value addition. Traders import pulses from MP and Maharashtra. Many time farmers have to face the situation like draught in the district. It's not only affect the farming but also affect the socioeconomic condition of farmer.

Therefore, instead of depend upon only farming farmers need to do some agribusiness by leveraging the opportunity of significant pulses production in that area of state. To cope with these situations this paper is an attempt to analyze instability of major pulse 
crop, consumption pattern, effective value chain as well as its preferred traits for the establishment of business opportunity in the selected district of Bihar.

\section{Materials and Methods}

Present study was predominantly based on collection of primary data for analyzing the preferred traits, consumption pattern as well value chain analysis of pulses. A sample of 270 famers of two districts consisting of 135 farmers from each districts were selected purposively as it is one of the important pulse trading centers of Bihar. The top 3village in Bhagalpur districts (near to Bihar Agricultural University, Sabour or research station).i.e. Khankitta, Rajpur, and Jicho and 3villages in the Banka district were Kotwal, Kotwali, and Babura were selected for the same. Thus a sample of 45 farmers from each village was interviewed. Stratified Random Sampling technique based on probability proportion to size method to farm size was used to conduct the interview. To compare the value - chain of chickpea through identified network involved in processing of dall and sattu, a sample of 10 wholesaler and 20 retailers of Bhagalpur and Banka market were also interviewed.

The time series data on area production and productivity of major pulses i.e. chickpea was collected from various government publications and websites for the year 199091to 2013-14 with main objective to analyze the growth trend and to suggest the agribusiness opportunity in the area. To find out the agribusiness opportunity in that area, preferred traits for marketing as well as consumption were also analyzed by using weighted scale mean.

To know the marketable surplus crop utilization pattern was worked out with simple average method. Consumption expenditure per household was also estimated to know proportion of income of individuals household expend on consumption of pulses as well as to find out the consumption pattern of selected villages/district under study.

\section{Statistical tools}

The growth rates in area, production and productivity of major pulses crop were estimated using exponential growth trend model.

$\mathrm{Y}=\mathrm{a} \cdot \mathrm{b}^{\mathrm{t}}$

Where:

$\mathrm{Y}=$ Area / production / productivity,

$\mathrm{a}=$ Intercept,

$\mathrm{b}=$ Regression coefficient,

$\mathrm{t}=$ Time variable,

From the estimated function, the compound growth rate was worked out by,

CGR $(r)=[$ Antilog $(\log b)-1] \times 100$

Where: $r=$ Compound growth rate

Degree of instability in area, production and productivity of chickpea:

The degree of instability in area production and productivity of chickpea was measured using coefficient of variation and coefficient of instability.

Coefficient of variation $($ C.V. $)=$ Standard deviation

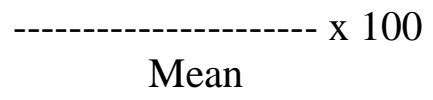

\section{Garrett's ranking technique}

Each of 135 respondents selected in each district were asked to rank the preferences based on their priorities using ranks from 1 to 10. In the next stage rank assigned to each 
reason by each individual was converted into per cent position using the following formula:

Per cent position $=100(\mathrm{Rij}-0.5) / \mathrm{NJ}$

Where,

Rij stands for rank given for the $\mathrm{i}^{\text {th }}$ factor ( $\mathrm{i}=$ $1,2 \ldots .5)$ by the $\mathrm{j}^{\text {th }}$ individual

$(j=1,2 \ldots \ldots, n)$ and $N_{j}$ stands for number of factors ranked by jth individual.

Once the per cent positions were found, scores were determined for each per cent position by referring Garrett's table. Then, the scores for each problem were summed over the number of respondents who ranked that factor. In this way, total scores were arrived at for each of the factors and mean scores were calculated by dividing the total score by the number of respondents who gave ranks. Final overall ranking of the factors was carried out by assigning rank $1,2,3 \ldots$ etc, in the descending order of the mean scores.

\section{Results and Discussion}

Since past few decades, the area under chickpea has been declined but productivity is more stable. In Bhagalpur, the average area under chickpea in triennium ending 2000 was 5042 hectare which producing 4416 tons with productivity of $872 \mathrm{~kg}$ per hectare. It shown an increasing trend in area and production during the triennium ending 2009 but productivity during the same has been declined to $744 \mathrm{Kg} / \mathrm{ha}$ (Kumari et al., 2015). Chickpea is also a major pulse crops in Banka district with an area of 3873 ha during 2000 after that it has declined to 2477 ha till 2009 triennium ending however average production has been stagnated over the same period but productivity level has shown an increasing trend as rises from $716 \mathrm{~kg} / \mathrm{ha}$ to $1057 \mathrm{Kg} / \mathrm{ha}$. This requires the suitable policy to develop the technology of processing, storage and sustainable production for the livelihood security of people in Bihar (AICRPs, 2011).

It could be seen that significantly less variation was observed in productivity i.e. 13.74 percent and 20.43 percent respectively in Bhagalpur and Banka district. It means that productivity of chickpea over the period has been almost increases in same rate, whereas very high coefficient of variation was observed in production (58.35per cent) and area $(57.79 \%)$ respectively for period under study period (Ranjan et al., 1998).

\section{Coefficient of instability}

The coefficient of variation measures the absolute variation while coefficient of instability which is also called as instability index measures the variation around the trend. It is a close approximation of the average year to year percentage variation adjusted for trend. Thus the variations around the trend are more pronounced than the absolute variation. D-trended data for the same indicated that highest variability of productivity was observed in Bhagalpur district of Bihar in 2003-12 followed by area under chickpea during the same period. However minimum variability was shown in 1997-2012. District wise analysis indicated that variability in area production was comparatively less in Banka however variability in productivity was found more in Bhagalpur district (Table 1).

The annual household consumption expenditure pattern of sample farmers in Bihar is shown in table above since rice is the main staple food for the farmers. Among the pulses group the expenditure on chick pea is more than that of pigeon pea and other pulses, because the price of pigeon pea was nearly Rs. 40-50/Kg costly only big farmers have been used for the purpose of consumption. The expenditure incurred on pulses was 
around $15.60 \%$ of total food expenditure. The food expense was around 60-62\% whereas non-food expense, like education was the single largest component on which the total expenses per sample was estimated as Rs 14000 in selected villages of Bihar. Findings supported the angel law, higher the income lowers the expenditure on food items and vice-versa (Reddy, 2004, 2009) (Table 2).

\section{Crop utilization pattern}

The crop utilization pattern of chickpea in selected district of Bihar indicated that, in Bhagalpur districts hardly a few farmers having large size of holding sold their traditional variety produced in market. Majority of farmers they produced for own consumption, followed by used for own seed. It may further observe that amount left for sold was as high as $460 \mathrm{~kg} / \mathrm{sample}$. For Banka similar trend was observed and they used to sell as seed was $215.5 \mathrm{~kg} / \mathrm{sample}$. It may be conclude that data pertaining to crop utilization of main product and by products of traditionally grown variety hardly sold in market by the farmers. It was mainly used for consumption purpose in both of district. (Kumari et al., 2015).

\section{Agribusiness opportunity for the farmers}

To find out agribusiness opportunity preferred traits for consumption and marketing was also analyzed and presented in table 3.

For the purposes of consumption it can be observed that those varieties having better taste followed by less cooking time for local variety and better taste along with having high keeping quality was preferred by most of the respondents for consumption

Those varieties having high demand was ranked first followed by fetching high price and low price fluctuation for $2^{\text {nd }}$ and $3^{\text {rd }}$ by most of the farmers for marketing purposes (Table 4). A few farmers had given $2^{\text {nd }}$ rank for improved variety that recovery $\%$ of dhal in improved variety was low. The technique of ranking was developed on the basis by wt. mean scale on the basis of Garrett's ranking score (mentioned in methodology).It may be concluded that higher yield of better taste having high demand in the market is the most preferred traits among cultivars for consumption and marketing of the produce of chickpea in Bihar (Shiyani et al., 1998).

Rains fed farmers in district have to face extreme climatic conditions. Sometime the good rain may not kind to farmers. That time farmers had to face financial loses in farming as it was their prime occupation. But if farmers can enter in subsidiary agribusiness with farming, it would be reduce the financial risk, means even if he could not get enough money from farming due to natural calamities, the subsidiary agribusiness can help them to sustain in that adverse situation. As chickpea is cheapest source of protein and has multipurpose use, especially in Bhagalpur district people used it as Bassoon, Sattu and whole chana dal and also as substitute of vegetable during the off season when the price of vegetable in market is very high, people could not afford to buy (Ranjan, 1996, 1998; Kumari et al., 2015). Despite of these facts available dal Mills in the region was very few in numbers. There are various agribusinesses opportunities available for the farmers like poultry, fishery, goat farming, sericulture, aqua-culture, food processing, packaging, etc. especially taking in to consideration the agro climatic condition of the district having abundant scope for pulse production and non-availability of dall mill in an area needs specific training facility for the rural youth in Bihar.

Mini dal mill is one of the good agribusinesses in that area. As it required less 
investment and farmers' can gets good return. It must be a scalable agribusiness opportunity of the area. It is because due to lack of processing dall mill wholesalers used to purchase dall from other place like Maharashtra, M.P and siliguri. As it was seen from the analysis of two net- work for transaction of chickpea in selected district of Bihar one was identified for marketing of dall and other identified network was for marketing of sattu.

Table.1 Area, production and productivity in selected districts (1997 to 2012) and Instability measures (Area in '000 ha and productivity in $\mathrm{kg} / \mathrm{ha}$ ) (Area in ' 000 ha and productivity in $\mathrm{kg} / \mathrm{ha}$ )

\begin{tabular}{|l|l|l|l|l|l|l|}
\hline & \multicolumn{3}{|l|}{ BHAGALPUR } & \multicolumn{3}{l|}{ BANKA } \\
\cline { 2 - 7 } & Area & Production & Yield & Area & Production & Yield \\
\hline $\mathbf{2 0 0 0}$ & 5042 & 4416 & 872 & 3873 & 2703 & 716 \\
\hline $\mathbf{2 0 0 3}$ & 3619 & 3012 & 823 & 3008 & 1836 & 745 \\
\hline $\mathbf{2 0 0 6}$ & 3144 & 2126 & 663 & 3561 & 2680 & 745 \\
\hline $\mathbf{2 0 0 9}$ & 6162 & 4619 & 744 & 2477 & 2783 & 1057 \\
\hline Instability measure & Raw data(c.v) \\
\hline $\mathbf{1 9 9 7 - 2 0 0 3}$ & 27.46 & 30.29 & 13.74 & 17.10 & 29.04 & 20.43 \\
\hline $\mathbf{2 0 0 3 - 1 2}$ & 83.63 & 83.63 & 23.09 & 40.27 & 54.33 & 31.94 \\
\hline $\mathbf{1 9 9 7 - 2 0 1 2}$ & 57.79 & 58.35 & 19.05 & 30.51 & 43.38 & 30.02 \\
\hline De-trended data(c.v) & 0.04 & 0.04 & 0.31 & 0.07 & 0.09 & 0.34 \\
\hline $\mathbf{1 9 9 7 - 2 0 0 3}$ & 0.24 & 0.10 & 0.43 & 0.07 & 0.08 & 0.26 \\
\hline $\mathbf{2 0 0 3 - 1 2}$ & 0.10 & 0.01 & 0.10 & 0.01 & 0.02 & 0.13 \\
\hline $\mathbf{1 9 9 7 - 2 0 1 2}$ & &
\end{tabular}

Source: (Directorate of Economics\& Statistics, Govt. of Bihar, estimated by authors)

Table. 2 Consumption expenditure of sample farmers, 2013-14 (Rs/Year)

\begin{tabular}{|l|c|c|c|}
\hline Food item & Bhagalpur & Banka & Pooled \\
\hline Cereals & 16290 & 12208 & 14249 \\
\hline Pulses & 9757 & 5173 & 7465 \\
\hline Milk and Milk products & 11660 & 13270 & 12465 \\
\hline Edible oils & 3214 & 2666 & 2940 \\
\hline Non-Veg. Foods & 4539 & 4597 & 4568 \\
\hline Fruits and vegetables & 4757 & 5467 & 5112 \\
\hline Others & 1068 & 997 & 1032.5 \\
\hline Total food expenditure & $\mathbf{5 1 2 8 5}$ & $\mathbf{4 4 3 7 8}$ & $\mathbf{4 7 8 3 1 . 5}$ \\
\hline Health & 5955 & 7544 & 6749.5 \\
\hline Education & 18298 & 11447 & 14872.5 \\
\hline Entertainment and travel & 1651 & 1871 & 7881 \\
\hline Clothing and shoes & 6702 & 9075 & 3020.5 \\
\hline Ceremonies & 2250 & 3791 & 1061 \\
\hline Alcohol and Cigarettes & 945 & 1177 & 1985.5 \\
\hline Cosmetics & 2064 & 1907 & 3822 \\
\hline Others & 1920 & 5724 & $\mathbf{4 1 1 6 0 . 5}$ \\
\hline Total Non-food & $\mathbf{3 9 7 8 5}$ & $\mathbf{4 2 5 3 6}$ & $\mathbf{8 8 9 9 2}$ \\
\hline Total expenditure & $\mathbf{9 1 0 7 0}$ & $\mathbf{8 6 9 1 4}$ & \\
\hline
\end{tabular}

Source: Field survey, 2013-14 
Table.3 Preferred traits for consumption among cultivars (Wt. scale)

\begin{tabular}{|l|c|c|c|c|}
\hline \multirow{2}{*}{ Preferred traits } & \multicolumn{2}{|c|}{ Bhagalpur } & \multicolumn{2}{c|}{ Banka } \\
\cline { 2 - 5 } & Local & Improved & Local & Improved \\
\hline Better taste & $1^{\text {st }}$ & $1^{\text {st }}$ & $1^{\text {st }}$ & $1^{\text {st }}$ \\
\hline Less cooking time & $3^{\text {rd }}$ & $2^{\text {nd }}$ & $2^{\text {nd }}$ & $2^{\text {nd }}$ \\
\hline High keeping quality & $2^{\text {nd }}$ & 3rd & $3^{\text {rd }}$ & 3 rd \\
\hline
\end{tabular}

Source: Field survey, 2013-14

Table.4 Preferred traits for marketing among cultivar

\begin{tabular}{|l|c|c|c|c|}
\hline \multirow{2}{*}{ Marketing PREFERED TRAITS } & \multicolumn{2}{|c|}{ BHAGALPUR } & \multicolumn{2}{c|}{ BANKA } \\
\cline { 2 - 5 } & Local & Improved & Local & Improved \\
\hline High demand & $1^{\text {st }}$ & $1^{\text {st }}$ & $2^{\text {nd }}$ & $1^{\text {st }}$ \\
\hline Fetches higher price & 2nd & $2^{\text {nd }}$ & $1^{\text {st }}$ & $2^{\text {nd }}$ \\
\hline Low price fluctuations & 3nd & $3^{\text {rd }}$ & $3^{\text {rd }}$ & $3^{\text {rd }}$ \\
\hline
\end{tabular}

Table.5 Comparison of value chain of dall vs. sattu

\begin{tabular}{|l|l|}
\hline Network 1(dall) & Network 2(sattu) \\
\hline $\begin{array}{l}\text { Producers share in consumer rupees was } \\
\text { estimated as } 68.86 \text { percent }\end{array}$ & $\begin{array}{l}\text { Producers share in consumer rupees was } \\
\text { estimated as31.11 percent }\end{array}$ \\
\hline Marketing cost was Rs5.05/Kg & Marketing cost was estimated Rs10.97/Kg \\
\hline Marketing margin was $12.95 / \mathrm{Kg}$ & Marketing margin was Rs51/Kg \\
\hline Total cost was Rs $18 / \mathrm{Kg}$ & Total cost was Rs62/Kg \\
\hline
\end{tabular}

\section{Marketing practices in study districts}

80 per cent farmers preferred local variety for own consumption.

Medium and large farmers: sell about 90 percent of the produce just after harvest. Out of the marketed surplus, 80- 85 per cent produce traded outside the state mainly to Siliguri and Kolkata for value addition. Traders import pulses from MP and Maharashtra.

The prevalent channels followed in this regard are as below

Producer - Village Trader - Dal Miller Wholesaler - Retailer - Consumer,

Producer - Dal Miller - Retailer - Consumer,

Producer - Wholesaler - Dal Miller - Retailer Consumer,

\section{Comparison of value chain of dall vs. sattu}

Two networks (network for dal and network for making sattu), were used to find out the producers share, marketing cost and margin at different channel to reach the produce from producers to ultimate consumers. It was estimated that in value addition the cost incurred was just double when we compare it with supply chain only and producers share was reduced to half i.e. 31 percent and margin taken by intermediaries' was3-4 times more in network two (Kumari et al., 2016) (Table 5).

It was also seen that due to lack of processing machine in Bihar commission agent were taking huge amount of margin i.e. Rs of $51 / \mathrm{kg}$ who were involved in marketing of sattu. Producers share was estimated only 32 percent in consumer's rupees. The cost of marketing estimated as Rs 11 which was double of the network- one i.e. network used for marketing of dall. The total cost of marketing of dall was 
estimated as Rs 18 as against sattu it was observed as Rs 62. It may be concluded that due to value addition the total cost of marketing has been increased. If these functions will be assumed by the producers it as a processor, cost as well as margin of profit taken by the commission agent will spread and finally benefit will be goes to the producers and consumers. Pulses in Bihar also go through a large supply chain which drives up the prices of consumers. This is generally due to large number of intermediaries who take their cut of the value of the pulses. Guy et al., (2001) also found similar results in their study on pigeon pea production systems, utilization and marketing in semi-arid lands of Kenya.

It is estimated that each middle men in the supply chain takes at least 1 to $2 \%$ commissions on their sales. There is a good scope for pulses industry also that's why special attention in these areas needs to explore the technology for optimization of pulse production in study distracts as well as state as a whole.

\section{Suggestions}

Establishment of mini dal mill as well as processing mills is one of the agribusiness opportunities for the farmers of Bihar to become an entrepreneurs'. Farmers, self-help group (SHG), small entrepreneur, unemployed youth can leverage this opportunity and can start their own agribusiness venture which is need of hours in Bihar for improving nutritional security as well bust up the farmers to increase the area under pulses. Government subsidy is also available for the same. Governments' main aim of the scheme is to enhance the productivity, efficiency of pulse crop and technology dissemination pertaining to pulse production in aforesaid area of Bihar. Dr. Panjab Rao Deshmukh Agricultural University, Akola, Maharashtra has developed a model "Mini Dal Mill". They are conducting training on working of Mini dal mill. We can approach the same institute to enhance the capacity building of rural youth to start own agribusiness venture in Bihar also.
In Bihar Agro climatic conditions are suitable for the pulse crops. The growth and instability of chickpea crop shows significant growth with respect to productivity however area and production over the period of time shown declining trend. Instead of depends upon only farming farmers can go for subsidiary agribusiness, "Mini dall mill" as well as processing of sattu is one of the good agribusiness opportunity in that area. As it required less investment and can gets good return. It will definitely be helpful to enhance the livelihood security of rural people in Bihar.

\section{References}

AICRPs (2011) Annual Report on Gram, Arhar, Moong, Urad, etc. undertaken by Indian institute of pulse research, Kanpur.

Anonymous (2012). Directorate of Economics and Statistics, Ministry of Agriculture and Cooperation Government of India.

Chopra, K. (1982) Pulse production in India- A state wise Analysis, Indian Journal of Argil. Economics37 (3): pp 371 - 380.

Directorate of Economics and Statistics (2011) Government of Bihar. Ministry of Agriculture and Cooperation Government of India.

Dubey, A. K., Srivastava, J. P. and Sharma, V. K. (2008). Attitude of respondents towards KVK training programmes. Indian Research Journal Extension Education. 8(2/3):78-80

F.A.O. Stat., (2009) Government of India 2000 Expert Committee Report on Pulses, Technology Mission on Oilseeds and Pulses, Department of Agricultural and Cooperation, Ministry of Agriculture, New Delhi.

Government of Bihar (2008), Bihar Economic Survey-2008-09, Ministry of Finance, Patna, March, pp.23.

Government of Bihar (2008), Bihar through Figure, Department of Statistics and Evaluation, Patna

Government of India (2008), Bihar's Agricultural Development: Opportunities and Challenges", A Report of the Special 
Task Force on Bihar, New Delhi, April, p.16.

Guy M., Paul K., Agnes M., Florence O., Cécile S., Paul A., Jean B., Alain L. R. (2001) Survey of pigeon pea production systems, utilization and marketing in semi-arid lands of Kenya, Biotechnol. Agron. Soc. Environ., 5 (3): 145-153.

Kumari, M., Meena, L. K. and Bairwa, S.L. (2015) Socio Economic Assessment of Chickpea Growers in Bihar, India. International Journal of Agricultural Science and Research (IJASR) 5 (4): 2128.

Kumari, M., Bairwa, S.L. and Meena, L. K. (2015) Preferred Traits and Economics of Pigeon Pea Cultivation in Selected District of Bihar. Progressive ResearchAn International Journal. 10 (4): 323327.

Kumari, M. and Bairwa, S.L. (2016) Trends in pigeon pea Area, production and productivity in India vs. Bihar. The Annals of Biology. 32 (1): 104-109.

Kumari, M.and Birwa, S.L. (2016) Socioeconomic Assessment of pigeon pea Growers in selected districts of Bihar. The Annals of Agri Bio Research. 21 (1): 101108.

Meena, L. K., Bairwa, S. L., Lakra, K., and Sirohiya, L. (2014). Analysis of the profile on participating and nonparticipating farmers in chickpea production

technology.AgriculturalUpdate9 (1): 31 36.

Ranjan, K. P and Singh, R.K.P. (1998) Cropping Pattern in Backward Agriculture - A Case of North Bihar. Agricultural Situation in India. pp. 69 72.
Ranjan, K. P. (1996) Pulse production in North Bihar during Post-green Revolution Period. The Bihar Journal of Agricultural Marketing. 4 (4):pp $407-416$.

R.P. Sahu, and Ram Jiyawan (2012) Comparative Economics of Pigeon pea Cultivation in the Farmers' Fields in Uttrakhand, Journal of Community Mobilization and Sustainable Development, 7(2): 171-174.

Reddy AA.2004. Consumption pattern, trade and production potential of pulses. Economic and Political Weekly 39(44): 4854-4860.

Reddy AA.2009. Pulses production technology: Status and way forward. Economic and Political Weekly44 (52): 73-80.

Shiyani RL, Joshi PK, Asokan M, Bantilan MC Sand Sethi SC.1998. Adoption of chickpea Varieties in Panchamahals district of Gujarat, Pages 10-113 in Assessing joint research impacts: Proceedings of an international workshop on joint Impact Assessment of NARS/ICRISAT Technologies for the Semi-arid Tropics, 2-4 Dec, 1996, ICRISAT, Patancheru, India.

Salam, M. A., Anwer, M. E. and Alam, M. S. (2013) an analysis Agriculture and the economy of Bihar: International Journal of Scientific and Research. 3(11) pp 1-19.

Suhasini, K, Girish, N.K., Bantilan, C. Charyulu, D. K., Rao, G.D.N., Jayalakshmi, V., Vijaykumar, A.G., Mannur, D.M., Satish, Y. Gaur, P.M. and Rao, K.P.C. (2013) Synthesis Report on Chickpea baseline and early adoption surveys in south Asia: insights from TL-II $\begin{array}{llllll}\text { Project. } & R . & R\end{array}$. No. 19, ICRISAT Hyderabad.

\section{How to cite this article:}

Meera Kumari, S.L. Bairwa, L.K. Meena and Rahaman, Sk.M. 2017. Agribusiness Opportunity for Pulse Growing Farmers in Bihar: A Situation Analysis. Int.J.Curr.Microbiol.App.Sci. 6(6): 26732681. doi: https://doi.org/10.20546/ijcmas.2017.606.318 